\title{
Minder and Pfluger Respond to "Electromagnetic Fields and Cancer in Railway Workers" by Savitz
}

\author{
C. E. Minder and D. H. Pfluger
}

We are grateful for the opportunity to reply to Dr. David Savitz's comments (1) on the findings of our study (2). Of necessity, we will concentrate on certain points, omitting others equally worthy of discussion.

Dr. Savitz outlines, with admirable clarity, an ideal epidemiologic study of the health effects of electromagnetic field (EMF) exposures. By such exacting standards, any real-life study is bound to fail, and the interesting question is how and to what extent. We believe that studies of railway personnel permit epidemiologists to get close to Dr. Savitz's ideal: Railway engine drivers have stable and predictable exposures to extremely low frequency EMFs $(\leq 100 \mathrm{~Hz})$, other carcinogens are largely absent, and sufficient personyears are available for study. Perhaps comparability of occupations is least guaranteed.

Dr. Savitz questions the contribution of studies of $16^{2} / 3-\mathrm{Hz}$ exposure to the larger question of population exposure. We think that studies of $16^{2} / 3-\mathrm{Hz}$ exposure are relevant, because there is solid evidence that exposure to extremely low frequency EMFs causes resonance phenomena in cells, affecting calcium ion concentrations (3-6). Resonance may initiate a biologic pathway even with low energies. In addition, large populations are exposed to $50-\mathrm{Hz}$ (namely, triple $162 / 3-\mathrm{Hz}$ ) extremely low frequency EMFs from household currents. Resonance effects observed at $16^{2} / 3 \mathrm{~Hz}$ mean that resonance will occur with exposures at or near low multiples $(60 \mathrm{~Hz})$ of this frequency as well. This conclusion is strengthened by the elevated leukemia risks found at the $16^{2} / 3 \mathrm{~Hz}$ level as well as at $50 \mathrm{~Hz}$ and $60 \mathrm{~Hz}$.

Dr. Savitz argues that the weak point of EMF research is the lack of a biologically plausible pathway. A review of the literature has convinced us otherwise. There is extensive evidence linking extremely low frequency EMF exposure to calcium ion concentrations (3-6), apoptosis (7), melatonin levels $(8,9)$, chromosome damage, and cancer (see discussion below). There is also evidence linking calcium ion balance to apoptosis (10), melatonin levels (11), chromosome damage, and cancer. For brevity, we shall restrict ourselves here to the evidence on chromosome damage, a precursor of

Received for publication January 2, 2001, and accepted for publication February 1, 2001.

Abbreviation: EMF, electromagnetic field.

From the Institute for Social and Preventive Medicine, University of Berne, Berne, Switzerland.

Reprint requests to Dr. C. E. Minder, Institute for Social and Preventive Medicine, University of Berne, Finkenhubelweg $11, \mathrm{CH}-$ 3012 Berne, Switzerland (e-mail: minder@ispm.unibe.ch). cancer. Nordenson et al. (12), Valjus et al. (13), and Skyberg et al. (14) have all found elevated levels of chromosome damage among workers exposed to extremely low frequency EMFs. Nordenson et al. $(15,16)$, Rosenthal and Obe (17), Khalil and Qassem (18), and Garcia-Sagredo and Monteagudo (19) have found elevated levels of chromosome damage in human cell lines after exposure to extremely low frequency EMFs. El Nahas and Oraby (20) found an extremely low frequency EMF dose-dependent increase in micronuclei of mouse somatic cells.

This biologic evidence, combined with the ample epidemiologic evidence of dose-response relations between leukemia and extremely low frequency EMF exposure, seems to us to satisfy Hill's criteria for causality (21). Thus, Dr. Savitz's suggestion of "a possible modest association" $(1$, p. 838$)$ could be misinterpreted. The risk ratios found for leukemia and extremely low frequency EMF exposure are similar in magnitude to those for lung cancer and passive smoking. Both of these associations may be modest in size; in our opinion, both are well established. The research cited above suggests that the association between extremely low frequency EMFs and leukemia may be causal. If this is the case, its public health impact will not be modest.

We agree with Dr. Savitz that "black box" epidemiology has made its contribution to solving this problem. We feel that now is the time to impartially assemble all of the available evidence on the biology and health effects of extremely low frequency EMF exposure. It would be fitting for the Society for Epidemiologic Research to initiate such an effort.

\section{ACKNOWLEDGMENTS}

The authors thank several colleagues for extensive and fruitful discussions. They also gratefully acknowledge the Swiss National Science Foundation for providing financial support (grant 32-32459.91) for the study.

\section{REFERENCES}

1. Savitz DA. Invited commentary: electromagnetic fields and cancer in railway workers. Am J Epidemiol 2001;153:836-8.

2. Minder CE, Pfluger DH. Leukemia, brain tumors, and exposure to extremely low frequency electromagnetic fields in Swiss railway employees. Am J Epidemiol 2001;153:825-35. 
3. Bawin SM, Kaczmarek LK, Adey WR. Effects of modulated VHF fields on the central nervous system. Ann N Y Acad Sci 1975;247:74-81.

4. Bawin SM, Adey WR. Sensitivity of calcium binding in cerebral tissue to weak electric fields oscillating at low frequency. Proc Natl Acad Sci U S A 1976;73:1999-2003.

5. Blackman CF, Benane SG, Elliott DJ, et al. Influence of electromagnetic fields on the efflux of calcium ions from brain tissue in vitro: a three-model analysis consistent with the frequency response up to $510 \mathrm{~Hz}$. Bioelectromagnetics 1988;9: 215-27.

6. Blackman CF. ELF effects on calcium homeostasis. In: Wilson BW, Stevens RG, Anderson LE, eds. Extremely low frequency electromagnetic fields: the question of cancer. Columbus, $\mathrm{OH}$ : Battelle Press, 1990:187-208.

7. Fanelli C, Coppola S, Barone R, et al. Magnetic fields increase cell survival by inhibiting apoptosis via modulation of $\mathrm{Ca} 2+$ influx. FASEB J 1999;13:95-102.

8. Burch JB, Reif JS, Yost MG, et al. Nocturnal excretion of urinary melatonin metabolite among electric utility workers. Scand J Work Environ Health 1998;24:183-9.

9. Burch JB, Reif JS, Yost MG, et al. Reduced excretion of a melatonin metabolite among workers exposed to $60 \mathrm{~Hz}$ magnetic fields. Am J Epidemiol 1999;150:27-36.

10. Balcer-Kubiczek EK. Experimental studies of electromagnetic field-induced carcinogenesis in cultured mammalian cells. In: Frey AH, ed. On the nature of electromagnetic field interaction with biological systems. New York, NY: Springer-Verlag New York, 1994:143-55.

11. Lerchl A, Reiter RJ, Howes KA, et al. Evidence that extremely low frequency $\mathrm{Ca}(2+)$ - cyclotron resonance depresses pineal melatonin synthesis in vitro. Neurosci Lett 1991;124:213-15.

12. Nordenson I, Mild KH, Ostman U, et al. Chromosome effects in lymphocytes of $400 \mathrm{kV}$-substation workers. Radiat Environ Biophys 1988;27:39-47.

13. Valjus J, Norppa H, Jarventaus H, et al. Analysis of chromosomal aberrations, sister chromatid exchanges and micronuclei among power linesmen with long-term exposure to $50-\mathrm{Hz}$ electromagnetic fields. Radiat Environ Biophys 1993;32:325-36.

14. Skyberg K, Hansteen IL, Vistnes AI. Chromosome aberrations in lymphocytes of high-voltage laboratory cable splicers exposed to electromagnetic fields. Scand J Work Environ Health 1993;19:29-34.

15. Nordenson I, Mild KH, Nordstrom S, et al. Clastogenic effects in human lymphocytes of power frequency electric fields. Radiat Environ Biophys 1984;23:191-201.

16. Nordenson I, Mild KH, Andersson G, et al. Chromosomal aberrations in human amniotic cells after intermittent exposure to 50 $\mathrm{Hz}$ magnetic fields. Bioelectromagnetics 1994;15:293-301.

17. Rosenthal M, Obe G. Effects of $50 \mathrm{~Hz}$ electromagnetic fields on proliferation and on chromosomal alterations in human peripheral lymphocytes untreated and pretreated with chemical mutagens. Mutat Res 1989;210:329-35.

18. Khalil AM, Qassem W. Cytogenetic effects of pulsing electromagnetic field on human lymphocytes in vitro: chromosome aberrations, sister-chromatid exchanges and cell kinetics. Mutat Res 1991;247:141-6.

19. Garcia-Sagredo JM, Monteagudo JL. Effect of low-level pulsed electromagnetic fields on human chromosomes in vitro: analysis of chromosome aberrations. Hereditas 1991;115: 9-11.

20. El Nahas SM, Oraby HA. Micronuclei formation in somatic cells of mice exposed to $50 \mathrm{~Hz}$ electric fields. Environ Mol Mutagen 1989;13:107-11.

21. Hill AB. The environment and disease: association or causation? President's address. Proc R Soc Med 1965;58:295-300. 